\title{
High proportion of Guillain-Barré syndrome associated with chikungunya in Northeast Brazil
}

\author{
Aline de Moura Brasil Matos, MD, Fernanda Martins Maia Carvalho, MD, PhD, Danielle Lima Malta, PhD, \\ Cleonisio Leite Rodrigues, MD, PhD, Alvina Clara Félix, MSc, Claudio Sergio Pannuti, PhD, \\ Amanda Dias da Rocha Lima, MSc, Danilo Lucas Alves Espósito, PhD, Leonilda Maria Barbosa dos Santos, PhD, \\ Felipe von Glehn, MD, PhD, FAAN, Jeová Keny Baima Colares, MD, PhD, \\ Benedito Antônio Lopes da Fonseca, MD, PhD, Augusto César Penalva de Oliveira, MD, PhD, and \\ Camila Malta Romano, PhD
}

Neurol Neuroimmunol Neuroinflamm 2020;7:e833. doi:10.1212/NXI.0000000000000833

From 2013 to 2015, sanitary authorities reported an increased incidence of Guillain-Barré syndrome (GBS) associated with Zika virus (ZIKV) in French Polynesia, Caribbean, and Brazil. ${ }^{1-3}$ After the end of ZIKV epidemics, GBS cases where still above the usual limits in countries where the arrival of chikungunya virus (CHIKV) was also a concern. ${ }^{3}$

Here, we report the findings from Hospital Geral de Fortaleza (HGF), a neuroinvasive arboviral disease vigilance center in Ceará State, Northeast Brazil.

\section{Methods}

We performed a prospective observational study that enrolled patients aged 15 year or older with the diagnosis of $\mathrm{GBS}^{4}$ (Brighton criteria I or II). All consecutive patients fulfilling the inclusion criteria from May 2015 to December 2017 were invited to participate.

Patients were evaluated for demographics, clinics (at admission and 6 months later), serum, and CSF complementary tests, and EMG. Owing to the local epidemics, besides investigating for classic GBS triggers, virologic tests for dengue virus, ZIKV, and CHIKV (i.e., ELISA IgM, IgG, and specific real-time PCR) were performed by a researcher blinded to clinical results. Neurofilament light chain ${ }^{5}$ (NfL) was measured in CSF and related to death, need for mechanical ventilation (MV), and incomplete recovery. CSF from 10 healthy subjects served as the control for NfL.

For comparison, official reports of arboviral systemic infections and total GBS cases/year from 2013 to 2017 were requested to the local state government according the Law \#12.527 November 18, 2011.

Continuous data were summarized as median and interquartile range (IQR). Categorical data were presented as counts and percentages. Kendall $\tau$ was used for correlations and MannWhitney test for comparisons. $p$ values $<0.05$ were deemed statistically significant. Data were analyzed using SPSS version 25.0. Graphs were constructed using Sigma Plot version 11.0. The study was approved by the HGF ethics committee (CAAE: 56572316.9.0000.5040) and the USP ethics committee (CAAE: 00274418.7.0000.0068) and conducted according to appropriate Brazilian regulations. All subjects provided written informed consent.

\author{
Correspondence \\ Dr. Romano \\ cmromano@usp.br
}



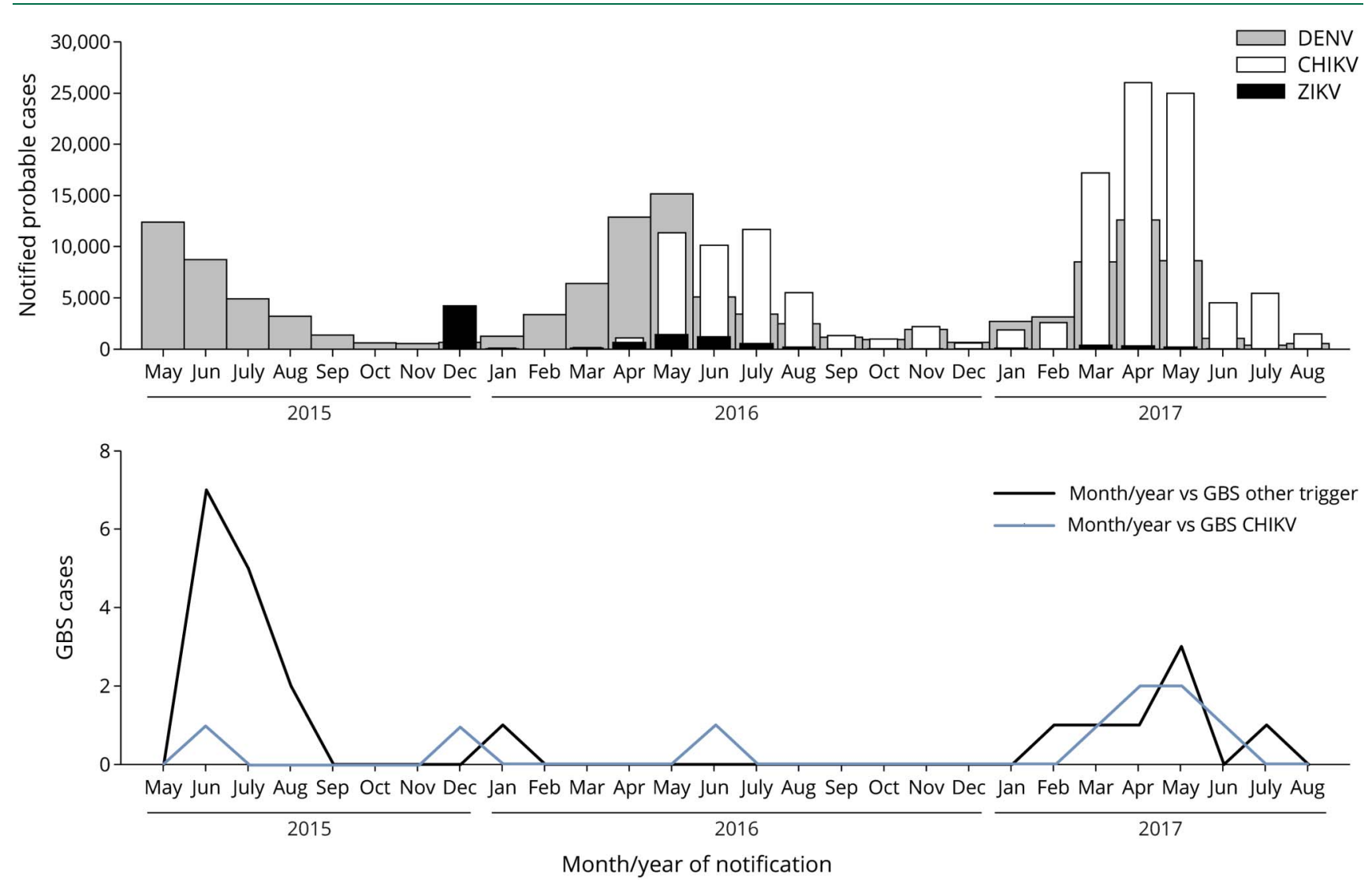

CHIKV = Chikungunya virus; DENV = Dengue virus; GBS = Guillain-Barré syndrome; ZIKV = Zika virus.

\section{Results}

A total of 42 patients with GBS suspicion were admitted. Eight patients were excluded (figure e-1, links.lww.com/ NXI/A278). From the 34 remaining, GBS trigger was attributed to CHIKV for 9 patients. ${ }^{6}$ For those, median age was 47 (IQR 31-55), 56\% were men and most without comorbidities (56\%). The mean number of GBS cases in the previous 2 years of the study was 52 cases/year; from 2015 to 2017, it was 88 cases/year. Most CHIKVGBS cases concentrated in the CHIKV epidemic peak (figure 1).

At admission, patients were confine to bed/wheelchair (56\%), walking with support (33\%), or unable to run (11\%). During in hospital stay, $22 \%$ required MV and no patient died. Median days in hospital were 16 (IQR 12-25.5). Recovery after 6 months was complete for $33 \%$, whereas $67 \%$ remained with minor signs or symptoms (table e-1, links.lww.com/NXI/ A278).

Major laboratory results can be found in supplementary material (links.lww.com/NXI/A278). EMG was primary demyelinating $(75 \%)$ or primary axonal $(25 \%)$. Although NfL presented higher titles than control (figure e-2), there was no correlation with death, MV or, recovery.

\section{Discussion}

We found that $26 \%$ of the cases enrolled were associated with $\mathrm{CHIKV}$ as an infectious trigger. The increase was coincident with the first local epidemics of CHIKV and followed a ZIKV epidemics. The association might be the result of a molecular mimicry autoimmune mechanism because CHIKV E1 glycoprotein shares homology with contactin-2, a protein present in the juxtaparanode. ${ }^{8}$

In one of the larger GBS cohort available, ${ }^{9}$ although no laboratory tests are mentioned, there are no reports of rash/arthralgia as prodromal symptoms. Despite that, reports of GBS-ZIKV associations are well known, ${ }^{1,3}$ unlike GBS-CHIKV which are rarely reported. Regarding clinical outcomes, differences are also apparent from our GBS-CHIKV to this same cohort. For recovery, all of our patients achieved Hugues score of " 0 " or " 1 " in 6 months (vs 61\%). No patient with GBS-CHIKV died (vs 7\%). As for MV, we have similar numbers (22\% vs $19 \%$ ).

A limitation of our study is the small sample size. This was unavoidable because of the rare nature of GBS disease and the seasonality of arbovirus infections. In addition, we were not able to access antiganglioside tests. However, we performed a clinical follow-up of at least 6 months and adopted strict criteria for GBS, allowing proper exclusion of diagnostic mimics. 
Our findings suggest CHIKV as an important trigger for GBS during epidemics, overcoming classic triggers as Campylobacter jejuni, Epstein-Barr virus, and influenza virus. Good outcomes were a commonplace in our study; however, sanitary authorities of areas affected by CHIKV should be aware of a possible increase in GBS incidence and as a consequence an increased necessity for intensive care unit beds and rehabilitation treatments.

\section{Acknowledgment}

The authors would like to thank Professor Steven S. Witkin from Weill Cornell Medicine for constructive comments and kindness in editing the manuscript, Vânia Maria Alves de Araujo from the Hospital Geral de Fortaleza for the laboratory assistance, and Rosa Maria Nascimento Marcusso from Instituto de Infectologia Emilio Ribas for the organizational support and revision of statistical analysis.

\section{Study funding}

$\mathrm{CNPq}$ /Brazil under the grant number 2016/407429 and Fundação de Amparo à Pesquisa do Estado de São Paulo-FAPESP/Brazil under the grants numbers 2014/26431-0 and 2019/03859-9.

\section{Disclosure}

A.d.M.B. Matos reports no disclosures. F.M. Maia Carvalho received research financial support from Conselho Nacional de Desenvolvimento Científico e Tecnológico CNPq/Brazil under the grant number 2016/407429. D.L. Malta, C.L. Rodrigues, A.C. Félix, C.S. Pannuti, A.d.R. Lima, and D.L.A. Espósito report no disclosures. L.M.B. dos Santos received research financial support from Fundação de Amparo à Pesquisa FAPESP/Brazil under the grant number 2014/26431-0. F. von Glehn, J.K.B. Colares, B.A.L. da Fonseca, and A.C.P. de Oliveira report no disclosures. C.M. Romano received research financial support from Programa de fomento as atividades de lideranças científicas dos LIMs do Hospital das Clínicas (PROFAP-LIM/HCFMUSP) \#10/2020. Go to Neurology.org/NN for full disclosures.

\section{Publication history}

Received by Neurology: Neuroimmunology \& Neuroinflammation January 21, 2020. Accepted in final form May 26, 2020.

Appendix Authors

\begin{tabular}{lll}
\hline Name & Location & Contribution \\
\hline $\begin{array}{l}\text { Aline de Moura } \\
\text { Brasil Matos, }\end{array}$ & $\begin{array}{l}\text { Universidade de São } \\
\text { MD }\end{array}$ & $\begin{array}{l}\text { Study concept and design, } \\
\text { data acquisition, analysis } \\
\text { and interpretation of the } \\
\text { data, and critical revision of } \\
\text { the manuscript from } \\
\text { important intellectual } \\
\text { content. }\end{array}$ \\
$\begin{array}{lll}\text { Fernanda } \\
\text { Martins Maia } \\
\text { Carvalho, MD, }\end{array}$ & $\begin{array}{l}\text { Fospital Geral de } \\
\text { PhD }\end{array}$ & $\begin{array}{l}\text { Study concept and design, } \\
\text { data acquisition, analysis and } \\
\text { interpretation of the data, } \\
\text { and critical revision of the } \\
\text { manuscript from important } \\
\text { intellectual content. }\end{array}$ \\
\hline
\end{tabular}

Appendix (continued)

\begin{tabular}{lll}
\hline Name & Location & Contribution \\
\hline $\begin{array}{ll}\text { Danielle Lima } \\
\text { Malta, PhD }\end{array}$ & Universidade de & $\begin{array}{l}\text { Study concept and design, } \\
\text { data acquisition, and } \\
\text { Fritical revision of the } \\
\text { manuscript from } \\
\text { important intellectual } \\
\text { content. }\end{array}$ \\
\end{tabular}

\begin{tabular}{|c|c|c|}
\hline $\begin{array}{l}\text { Cleonisio Leite } \\
\text { Rodrigues, MD, } \\
\text { PhD }\end{array}$ & $\begin{array}{l}\text { Hospital Geral de } \\
\text { Fortaleza }\end{array}$ & $\begin{array}{l}\text { Study concept and design, } \\
\text { data acquisition, and } \\
\text { critical revision of the } \\
\text { manuscript from } \\
\text { important intellectual } \\
\text { content. }\end{array}$ \\
\hline
\end{tabular}

\begin{tabular}{lll}
\hline $\begin{array}{l}\text { Alvina Clara } \\
\text { Félix, MSc }\end{array}$ & Universidade de São & $\begin{array}{l}\text { Data acquisition and } \\
\text { critical revision of the } \\
\text { manuscript from } \\
\text { important intellectual } \\
\end{array}$ \\
& content.
\end{tabular}

\begin{tabular}{lll}
\hline Claudio Sergio & Universidade de São & $\begin{array}{l}\text { Critical revision of the } \\
\text { manuscript from } \\
\text { Pannuti, PhD }\end{array}$ \\
& Paulo & $\begin{array}{l}\text { important intellectual } \\
\text { content. }\end{array}$
\end{tabular}

\begin{tabular}{lll}
\hline $\begin{array}{l}\text { Amanda Dias da } \\
\text { Rocha Lima, } \\
\text { MSc }\end{array}$ & $\begin{array}{l}\text { Universidade de } \\
\text { Campinas }\end{array}$ & $\begin{array}{l}\text { Data acquisition and } \\
\text { critical revision of the } \\
\text { manuscript from } \\
\text { important intellectual } \\
\text { content. }\end{array}$ \\
\hline $\begin{array}{l}\text { Danilo Lucas } \\
\text { Alves Espósito, } \\
\text { PhD }\end{array}$ & Universidade de São & $\begin{array}{l}\text { Data acquisition and } \\
\text { critical revision of the } \\
\text { manuscript from } \\
\text { important intellectual } \\
\text { content. }\end{array}$ \\
\hline $\begin{array}{l}\text { Leonilda Maria } \\
\text { Barbosa dos } \\
\text { Santos, PhD }\end{array}$ & Universidade de & $\begin{array}{l}\text { Data acquisition and } \\
\text { critical revision of the } \\
\text { Campinas }\end{array}$ \\
& & $\begin{array}{l}\text { manuscript from } \\
\text { important intellectual } \\
\text { content. }\end{array}$ \\
\hline
\end{tabular}

\begin{tabular}{lll}
\hline Felipe von & Universidade de & Data acquisition and \\
Glehn, MD, PhD, & Campinas & $\begin{array}{l}\text { critical revision of the } \\
\text { manuscript from } \\
\text { FAAN }\end{array}$ \\
& & important intellectual \\
& content.
\end{tabular}

\begin{tabular}{|c|c|c|}
\hline $\begin{array}{l}\text { Jeová Keny } \\
\text { Baima Colares, } \\
\text { MD, PhD }\end{array}$ & $\begin{array}{l}\text { Universidade de } \\
\text { Fortaleza }\end{array}$ & $\begin{array}{l}\text { Critical revision of the } \\
\text { manuscript from } \\
\text { important intellectual } \\
\text { content. }\end{array}$ \\
\hline $\begin{array}{l}\text { Benedito } \\
\text { Antônio Lopes } \\
\text { da Fonseca, MD, } \\
\text { PhD }\end{array}$ & $\begin{array}{l}\text { Universidade de São } \\
\text { Paulo, Ribeirão Preto }\end{array}$ & $\begin{array}{l}\text { Data acquisition and } \\
\text { critical revision of the } \\
\text { manuscript from } \\
\text { important intellectual } \\
\text { content. }\end{array}$ \\
\hline $\begin{array}{l}\text { Augusto César } \\
\text { Penalva de } \\
\text { Oliveira, MD, } \\
\text { PhD }\end{array}$ & $\begin{array}{l}\text { Instituto de } \\
\text { Infectologia Dr. Emilio } \\
\text { Ribas, São Paulo }\end{array}$ & $\begin{array}{l}\text { Study concept and design, } \\
\text { analysis and } \\
\text { interpretation of the data, } \\
\text { and critical revision of the } \\
\text { manuscript from } \\
\text { important intellectual } \\
\text { content. }\end{array}$ \\
\hline $\begin{array}{l}\text { Camila Malta } \\
\text { Romano, PhD }\end{array}$ & $\begin{array}{l}\text { Universidade de São } \\
\text { Paulo and hospital das } \\
\text { Clinicas, São Paulo }\end{array}$ & $\begin{array}{l}\text { Study concept and design, } \\
\text { data acquisition, analysis } \\
\text { and interpretation of the } \\
\text { data, and critical revision } \\
\text { of the manuscript from } \\
\text { important intellectual } \\
\text { content. }\end{array}$ \\
\hline
\end{tabular}




\section{References}

1. Cao-Lormeau VM, Blake A, Mons S, et al. Guillain-Barre syndrome outbreak associated with Zika virus infection in French polynesia: a case-control study. Lancet 2016; 387:1531-1539.

2. Arias A, Torres-Tobar L, Hernández G, et al. Guillain-Barré syndrome in patients with a recent history of Zika in Cucuta, Colombia: a descriptive case series of 19 patients from December 2015 to March 2016. J Crit Care 2017;37:19-23.

3. Mehta R, Soares CN, Medialdea-Carrera R, et al. The spectrum of neurological disease associated with Zika and chikungunya viruses in adults in Rio de Janeiro, Brazil: a case series. PLoS Negl Trop Dis 2018;12:e0006212.

4. Fokke C, van den Berg B, Drenthen J, Walgaard C, van Doorn PA, Jacobs BC. Diagnosis of Guillain-Barre syndrome and validation of Brighton criteria. Brain 2014; $137: 33-43$.
5. Rajabally YA, Uncini A. Outcome and its predictors in Guillain-Barre syndrome. J Neurol Neurosurg Psychiatry 2012;83:711-718.

6. Center for Disease Control and Prevention. Arboviral diseases, neuroinvasive and non-neuroinvasise 2015 case definition. In: NNDSS, ed. Available at: wwwn.cdc.gov/ nndss/conditions/arboviral-diseases-neuroinvasive-and-non-neuroinvasive/case-definition/2015/2015. Accessed January 2020.

7. Reddy V, Desai A, Krishna SS, Vasanthapuram R. Molecular mimicry between chikungunya virus and host components: a possible mechanism for the arthritic manifestations. PLoS Negl Trop Dis 2017;11:e0005238.

8. Masuda T. Contactin-2/TAG-1, active on the front line for three decades. Cell Adhes Migration 2017;11:524-531.

9. Doets AY, Verboon C, van den Berg B, et al. Regional variation of Guillain-Barre syndrome. Brain 2018;141:2866-2877. 


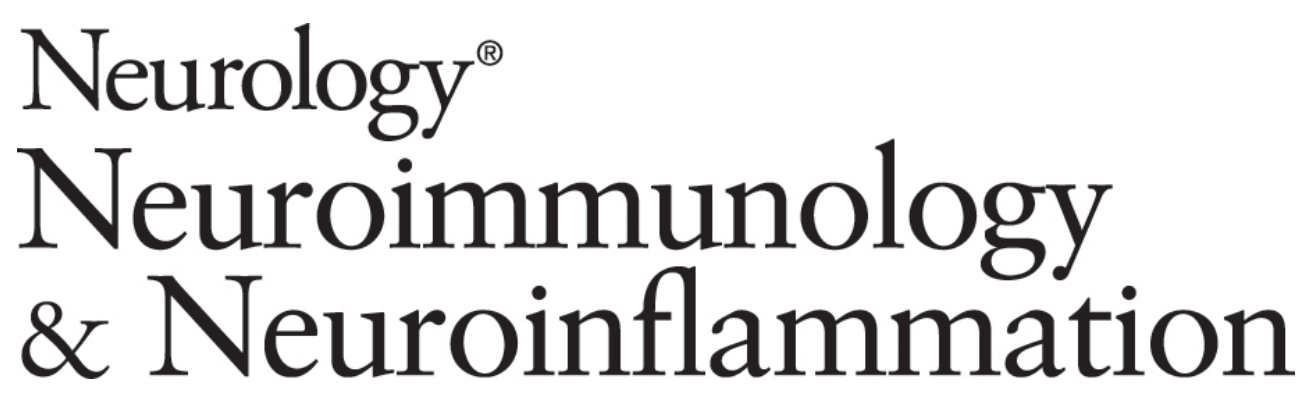

High proportion of Guillain-Barré syndrome associated with chikungunya in Northeast Brazil

Aline de Moura Brasil Matos, Fernanda Martins Maia Carvalho, Danielle Lima Malta, et al. Neurol Neuroimmunol Neuroinflamm 2020;7;

DOI 10.1212/NXI.0000000000000833

This information is current as of July 6, 2020

Neurol Neuroimmunol Neuroinflamm is an official journal of the American Academy of Neurology.

Published since April 2014, it is an open-access, online-only, continuous publication journal. Copyright

Copyright $\odot 2020$ The Author(s). Published by Wolters Kluwer Health, Inc. on behalf of the American

Academy of Neurology.. All rights reserved. Online ISSN: 2332-7812.

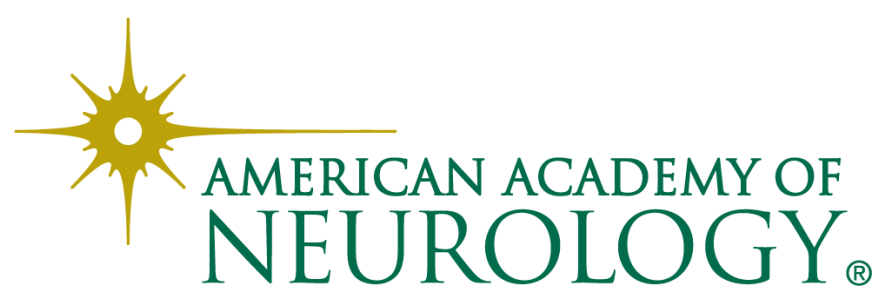




\section{Updated Information \& Services}

References

Subspecialty Collections

Permissions \& Licensing

\section{Reprints}

including high resolution figures, can be found at: http://nn.neurology.org/content/7/5/e833.full.html

This article cites 8 articles, 1 of which you can access for free at: http://nn.neurology.org/content/7/5/e833.full.html\#\#ref-list-1

This article, along with others on similar topics, appears in the following collection(s):

\section{All Infections}

http://nn.neurology.org//cgi/collection/all_infections

Autoimmune diseases

http://nn.neurology.org//cgi/collection/autoimmune_diseases

Guillain-Barre syndrome

http://nn.neurology.org//cgi/collection/guillainbarre_syndrome Post-infectious

http://nn.neurology.org//cgi/collection/postinfectious_

\section{Viral infections}

http://nn.neurology.org//cgi/collection/viral_infections

Information about reproducing this article in parts (figures,tables) or in its entirety can be found online at:

http://nn.neurology.org/misc/about.xhtml\#permissions

Information about ordering reprints can be found online: http://nn.neurology.org/misc/addir.xhtml\#reprintsus

Neurol Neuroimmunol Neuroinflamm is an official journal of the American Academy of Neurology.

Published since April 2014, it is an open-access, online-only, continuous publication journal. Copyright

Copyright $\odot 2020$ The Author(s). Published by Wolters Kluwer Health, Inc. on behalf of the American Academy of Neurology.. All rights reserved. Online ISSN: 2332-7812.

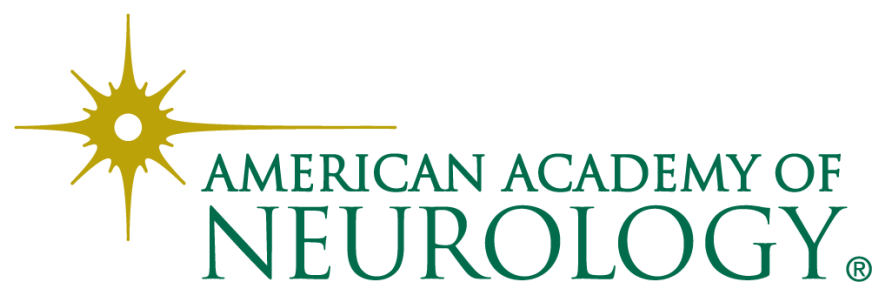

